\title{
PROTECTING THE PHYSICIAN IN HIV MISDIAGNOSIS CASES
}

\author{
CAITLIN A. SCHMID \\ INTRODUCTION
}

Tom Davis' physician informed him that his HIV test had come out positive, indicating he had the virus that causes Acquired Immune Deficiency Syndrome (AIDS). "I was bawling my eyes out," Davis said. "He . . . gave me a death sentence and walked out."1 After one month, Davis learned that the test had in fact been a "false positive": he did not actually have the disease. Davis brought a suit for negligent infliction of emotional distress against his physician and the hospital, asking for a written apology and symbolic compensation of $\$ 400$. David Thompson, Davis' lawyer, said: "An HIV test means so much more than just sticking a needle in someone's arm. With a positive result you may not be able to get insurance, establisl a mortgage or buy a car."2

In a more severe case, a man lived with the certainty that he had the HIV virus for nearly six years before learning that he had been misdiagnosed. ${ }^{3}$ During those years, Lon Blatteau had undergone treatment for AMS, even taking Azidothymidine-the drug more commonly known as AZT. When lie learned of the misdiagnosis, Blatteau filed suit against his physician for negligent infliction of emotional distress. According to attorney David Curtin, someone in Blatteau's position is "in no inan's land. He is HIVnegative but for years he has taken drugs designed for people that are HIV-positive." Blatteau said that the misdiagnosis "ruined [his] life."

AIDS is well known to be fatal, and the reaction of those misdiagnosed with HIV is understandably one of anger and dis-

1. Jennifer Ditchburn, Man Sues Doctor Who Allegedly Misdiagnosed AIDS Virus: Negative Result Was Revealed Month After First Diagnosis, OTTAWA CTIIZEN, July 23, 1995, at A5.

2. Id.

3. See Michael Kelly, HIV Positive Result Wrong, OMAHA WORLD-HeRALD, June 24, 1995, available in $1995 \mathrm{WL} 4078397$.

4. Id.

5. Id. 
tress. Between 1981 and 1991, it is estimated, 100,000 people in the United States died of AIDS. ${ }^{6}$ The fear surrounding AIDS is heightened by several characteristics of the disease. First, an infected individual may display no physical symptoms but still be

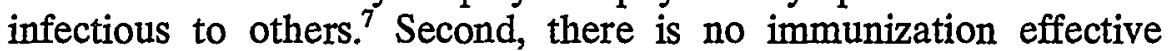
against AIDS and no known cure. Third, the disease manifests itself in a number of frightening ways, from fungus to dementia, and is invariably fatal. ${ }^{8}$

The medical technology used to combat AIDS is new, uncertain, and imperfect. The test niost often used to screen for HIV, the enzyme-linked immunosorbent assay test (ELISA), ${ }^{9}$ typically produces a small number of false positives, though misdiagnoses are rare. ${ }^{10}$ Cases like those brought by Davis and Blatteau are usually prompted by the imperfections in the medical technology itself rather than any alleged neghigence of the treating physician. ${ }^{11}$ These lawsuits against physicians discourage not the negli-

6. See Center for Disease Control, Mortality Attributable to HIV Infection/AIDSUnited States, 1981-90, 40 MORBDITY \& MORTALITY WKLY. REP. 41, 43 (1991).

7. See Helena Brett-Smith \& Gerald H. Friedland, Transmission and Treatment, in AIDS LAW TODAY 18, 22 (Scott Burris et al. eds., 1993).

8. See Mervyn F. Silverman, AIDS Medical Education for Lawyers, Judges, and Legislators, in AIDS AND THE COURTS 27, 31 (Clark C. Abt \& Kathleen M. Hardy eds., 1990).

9. See Hill v. Evans, No. CIV.A.91-A-626-T, 1993 WL 595676, at $\approx 2$ (M.D. Ala. Oct. 7,1993$)$. The ELISA is used as the first screen for HIV. Id. The ELISA test is relatively cheap (costs at private laboratories range from $\$ 15$ to $\$ 65$ ) and reliable (the number of false positives has been estimated to be $.15 \%$ ). See Josephine A. Mauskopf et al., Economic Impact of Treatment of HIV-positive Pregnant Women and Their Newborns with Zidovudine: Implications for HIV Screenings, JAMA, July 10, 1996, at 132, 135. Other sources differ as to reliability of the ELISA. See, e.g., PAUL G. FANNHAM ET AL, U.S. Dept. Health \& Human Servs., Public Health Reps., Counseling and TestING FOR HIV PREVENTION: COSTS, EFFECTS, AND COST-EFFECTIVENESS OF MORE RAPID SCREENING TESTS 13 (1996), available in 1996 WL 9871637; Hill, 1993 WL 595676, at $\$ 2$ ("[I]f everyone were to be tested for the HIV virus, then possibly nine out of every ten positive results could be false. If tests are run in 'high risk' groups, however, then the reliability of the results is over $90 \%$."). In either case, the test, "designed to be as sensitive as possible in order to decrease the likelihood of false negative readings[,] . . is susceptible to false positive readings." Hall v. Regents of Univ. of Cal. 51 Cal. Rptr. 2d 387, 389 (1996). The Center for Disease Control has strongly recommended that a second test, usually the "Western Blot" test, be performed should the ELISA reveal HIV antibodies. See Harris v. Thigpen, 941 F.2d 1495, 1499 n.3 (11th Cir. 1991).

10. See, e.g., Hall, 51 Cal. Rptr. $2 \mathrm{~d}$ at 389.

11. This is not to say that some of these cases may not involve negligence on the part of the physician. This negligence would involve the manner in which the physician relayed the results of the test to the patient, or the physician's failure to inform the patient of the slight imperfection of the ELISA test and the necessity of undergoing a 
gence of physicians, but rather, the willingness of physicians to administer the ELISA test. ${ }^{12}$ Thus, the distress of the individuals misdiagnosed with HIV inust be weighed against the importance of encouraging physicians to use these nascent tests. ${ }^{13}$

The few courts that have addressed emotional distress dainages in HIV misdiagnosis cases unfortunately follow one of two paths. This Note will focus on three cases which have reached the higher courts: Heiner v. Moretuzzo, ${ }^{14}$ R.J. v. Humana of Flori$d a,{ }^{15}$ and Chizmar v. Mackie. ${ }^{16}$ In Heiner and R.J., the courts denied the plaintiffs' claims on the grounds that the false positive diagnosis produced no physical injury. ${ }^{17}$ In Chizmar the court recognized the plaintiff's right to emotional distress dainages, basing the damages on the duty established by the physician-patient relationship. ${ }^{18}$

This Note argues that neither of these approaches adequately addresses the issues involved. Given the genuine and foreseeable suffering these patients inust experience, the physical injury requirenrent is outdated, and is potentially both under- and overinclusive in allowing dainages: under-inclusive in that it may deny

second, more precise test. This Note argues that the importance of remedying these instances of negligence on the part of the physician does not outweigh the importance of releasing the results of the AIDS test, and that unless the neghigence constitutes gross negligence, or the reporting is done in bad faith, the physician should be protected against liability. See, e.g., Frederick R. Fahmer, Comment, The Physician's Duty to Warn Non-Patients: AIDS Enters the Equation, 5 COOLEY L. REV. 353, 359 (1988) (stating that a physician should not be held liable to a patient "even where the physician's diagnosis is erroneous, unless the physician acted negligently in making his diagnosis").

12. An alternative to the physician-admimistered ELISA is the mail-in HIV test. This test was recently approved by the U.S. Food \& Drug Administration. See Tom Camey, Despite Concerns, Home HIV Tests Are Here to Stay, DES MONES REG., Sept. 9, 1996, available in $1996 \mathrm{WL} 6253527$. However, there is a concern that such tests will increase the number of false positive results. See id at $* 7$.

In addition, a new, "rapid HIV screening test" has been approved by some hospitals. See Paul G. Famham et al., Counseling and Testing for HNV Prevention: Costs, Effects, and Cost-Effectiveness of More Rapid Screening Tests, PUB. HEALTH REP., Jan. 11, 1996, available in 1996 WL 9871637. Rapid HIV screening tests are "designed to be used as a single assay and take 10 minutes or less on average." Id.

13. Laboratories may also be liable for false positives due to their involvement in the testing process, but the nature of that liability is beyond the scope of this Note.

14. 652 N.E.2d 664 (Ohio 1995).

15. 625 So. $2 d 116$ (Fla. Dist. Ct. App. 1993), affd in relevant part, 652 So. $2 d 360$ (Fla. 1995).

16. 896 P.2d 196 (Alaska 1995).

17. See Heiner, 652 N.E.2d at 670; R.J., 625 So. $2 \mathrm{~d}$ at 117.

18. See Chizmar, 896 P.2d at 214. 
recovery in the case of genuine inental suffering, over-inclusive in that it may allow a court to award damages for insignificant physical harm rather than for the emotional harm that is the real injury. However, due to the public policy need to protect physicians from liability in soine of these cases, ${ }^{19}$ the physical injury requirement should be replaced rather than rejected. A balance must be struck between recognizing genuine emotional distress and protecting physicians from unlimited habilities. Courts should apply a good faith immunity standard, which would recognize the difficulty of administering to patients with certaim illnesses and would protect physicians from hability where the physician acts in good faith.

Part I of this Note discusses the restrictiveness of the physical injury requirement. It reviews the history of emotional distress damages and the current use of the physical injury requirement, including its use by the courts in two of the three HIV misdiagnoses cases. It then discusses the "fear of future disease" cases as a model for breaking free of the physical injury requireinent. Part II argues that the physical injury requirement is outdated, but that the current alternative-using the physician-patient relationship as a basis for recovery-carries with it at least two dangers. First, by allowing patients to sue their physicians for emotional distress, courts are also exposing physicians to expansive third-party claims. This danger is illustrated in "recovered meinory" therapy cases, where courts have held doctors liable to individuals outside of the physician-patient relationship. Second, allowing recovery when HIV is misdiagnosed confuses cutting-edge medical technology's uncertainties with physician neghigence. This type of confusion is also apparent in cases involving Pap sinears, in which physicians have repeatedly been held hable for imperfect technology.

Part III analyzes the final HIV misdiagnosis case, arguing that courts must consider the effects of physician liability on the use of miperfect but necessary testing and thereby acknowledge a societal, not individual, view of emotional well-being in the face of epidemic. Part IV concludes that courts should approach HIV misdiagnosis cases by granting good faith immunity to physicians through the "professional judgment rule."

19. See discussion infra Sections II.A-B. 


\section{The PHysical INJURY REQUIREMENT}

\section{A. Standards of Recovery for Emotional Distress}

Traditionally, damages for emotional distress have been predicated upon the existence of some coincident physical injury. ${ }^{20}$ Courts have objected to permitting recovery in the absence of a tangible injury for various reasons. First, mental disturbance is difficult to measure in terms of money and thus arguably should not be the basis for a cause of action. ${ }^{21}$ Second, it is difficult to establish that inental disturbance is proximately caused by a defendant's action. ${ }^{22}$ Third, courts fear that a vast increase in litigation would ensue based on claims of less than serious emotional distress if recovery were generally allowed. ${ }^{23}$ Courts responded to these concerns by creating various physical injury tests for ensuring the validity of the alleged harm. At different times, courts have embraced the contemporaneous pliysical injury test or the "impact requirement;", 24 the "zone of danger" test;" and the "resultant pliysical harm" test. ${ }^{26}$

20. See, e.g., Mitchell v. Rochester Ry. Co., 45 N.E. 354, 354 (N.Y. 1896); Spade v. Lynn \& B.R. Co., 47 N.E. 88, 89 (Mass. 1897).

21. See, e.g., Mitchell, 45 N.E. at 354 (stating that if the defendant were negligent "we think the ... cases, as well as public policy, fully justify us in holding that the plaintiff cannot recover").

22. See, e.g., Payton v. Abbott Labs, 437 N.E.2d 171, 180 (Mass. 1982) (explaining that the injury requirement determines boundaries of proximate cause and provides proof of genuineness of claim).

23. See Spade, 47 N.E. at 89 (explaining that the rule prohibiting recovery for mental distress which is unaccompanied by physical harm is justified because allowing recovery for such claims "would open a wide door for unjust claims"); see also Knaub v. Gotwalt, 220 A.2d 646, 647 ( $\mathrm{Pa}$. 1966) (noting that if the courts allowed recovery for emotional distress in the absence of physical injury or impact the "[c]ourts would be swamped by a virtual avalanche of cases for damages for many situations and cases hitherto unrecoverable").

24. Under the "impact requirement," a plaintiff may not recover for emotional distress unless he has been actually physically affected by the action which caused the distress. See, e.g., Comfax Corp. v. North American Van Lines, Inc., 587 N.E.2d 118, 127 n.11 (Ind. Ct. App. 1992) (stating that accompanying physical impact must occur prior to or simultaneously with the infliction of emotional distress); see also Knaub, 220 A.2d at 647 (stating that "there can be no recovery of damages for imjuries resulting from friglt or nervous shock or mental or emotional disturbances or distress, unless they are accompanied by physical injury or physical impact").

25. The "zone of danger" test requires that the plaintiff was near enough to the activity causing the emotional distress to have been in personal danger of physical injury. See, e.g., Guilmette v. Alexander, 259 A.2d 12, 14 (Vt. 1969) (denying recovery to plaimtiff mother who witnessed the severe injury of her child but was not herself within the zone of plyysical danger).

26. The "resultant physical harm" test requires that a plamtiff's enotional distress 
However, the arguments in favor of requiring a physical injury have, appropriately, been increasingly criticized by inodern courts. ${ }^{27}$ Courts, astutely recognizing that emotional distress may be just as painful as a physical injury, if not nore so, have begun to hold that "[a] person's psychic well-being is as inuch entitled to legal protection as is his physical well-being."28 The physical injury requirement for "fear of disease" cases ${ }^{29}$ has been criticized as an "adherence to procrustean principles which have httle or no reseinblance to medical realities."30 This statement nakes sense in hight of the specificity and reliability of current psychiatric evaluations. It is inore desirable to allow a court to judge whether einotional harin warrants recovery on a flexible, case-by-case basis, with the help of expert testimony, than to rely on the arbitrary existence of an accompanying physical injury. ${ }^{31}$

The removal of the physical injury requirement ${ }^{32}$ permits a neghigence cause of action for the infliction of serious emotional distress. ${ }^{33}$ New York, for example, recognizes a general duty to avoid negligent infliction of enotional distress. ${ }^{34}$ Hawaii has also

manifest itself in some physical mjury. See, e.g., St. Charles v. Kender, 646 N.E.2d 411, 414 (Mass. App. Ct.) (denying recovery because plaintiff failed to introduce expert evidence demonstrating that her physical injury was caused by her emotional distress), review denied, 648 N.E.2d 1286 (Mass. 1995).

27. See Mary Donovan, Is the Injury Requirement Obsolete in a Claim for Fear of Future Consequences? 41 UCLA L. REV. 1337, 1354 (1994) (noting that "[s]everal courts and legal scholars have condemned the physical injury requirement as 'an artificial device' that is both 'overinclusive' and 'underinclusive' as a screening mechanism").

28. Gammon v. Osteopathic Hosp. of Me., Inc., 534 A.2d 1282, 1283 (Me. 1987); see also infra notes 32-38 and accompanying text.

29. Fear of potential disease cases differ significantly from the misdiagnosis cases. The fear of disease cases arise from situations in which the plaintiff has been negligently exposed to cancer or AIDS and brings a suit for the emotional distress resulting from such exposure. See generally Donovan, supra note 27, at 1369-70.

30. Scott D. Marrs, Mind Over Body: Trends Regarding the Physical Injury Requirement in Negligent Infliction of Emotional Distress and "Fear of Disease" Cases, 28 TORT \& INS. L.J. 1, 35 (1992) (quoting Taylor v. Baptist Med. Ctr., Inc., 400 So. 2d 369, 379 (Ala. 1981)).

31. See, e.g., Donovan, supra note 27 , at 1379.

32. See Marrs, supra note 30, at 4, 39; see, e.g., Gammon, 534 A.2d at 1285 (noting that the analyses of commentators and the developing trend in case law encourages abandonment of "artificial devices" and turns instead to reliance "upon the trial process for protection against fraudulent claims").

33. See, e.g., Abourezk v. N.Y. Airlines, Inc., 895 F.2d 1456 (D.C. Cir. 1990) (citations omitted) (requiring emotional disturbance of "so acute a nature that harmful physical consequences might not be unlikely to result"); Gammon, 534 A.2d at 1284 (allowing claim of severe emotional distress without a showing of physical impact).

34. See, e.g., Kennedy v. McKesson Co., 448 N.E. 2d 1332, 1335 (N.Y. 1983) (requir- 
held that "freedom from ... mental distress is entitled to independent legal protection," if that distress is severe, genuine, and foreseeable. ${ }^{35}$ California has extended the scope of recovery for emotional distress even further, allowing jurors to assess the emotional injury as presented by expert witnesses, stressing that where the einotional harm would commonly be accepted as being severe, recovery should be permitted. ${ }^{36}$ The states following this trend place greater rehiance on the tort law priniciples of duty and proximate cause to determine emotional distress damages, ${ }^{37}$ asking whether the mental distress is genuine, serious and reasonably foreseeable. ${ }^{38}$

B. Physical Injury Requirement and HIV Misdiagnoses: Heiner v. Moretuzzo and R.J. v. Humana of Florida

Of the HIV misdiagnosis cases that have been tried, several have been dismissed for lack of a concomitant physical injury. In Heiner v. Moretuzzo the plaintiff brought actions for negligent misdiagnosis of HIV against her physician, the hospital, and the laboratory that perforned the HIV testing. The court simply held: "Ohio does not recognize a claim for neghigent infliction of serious emotional distress where tlie distress is caused by the plaintiff's fear of a nonexistent physical peril." ${ }^{39}$ While the court noted that exceptions to the "actual peril" requirement did exist, ${ }^{40}$ they refused to apply them to the case at bar or to create a new exception. The court stated that it was not willing "to create a 'subspecies' of the tort of neghigent infliction of emotional distress that apphies only in the context of the patient-physician relationship." ${ }^{21}$

ing that defendant owes a special duty to plaintiff before plaintiff may recover).

35. Rodrigues v. State, 472 P.2d 509, 520 (Haw. 1970).

36. See Molien v. Kaiser Found. Hosps., 616 P.2d 813, 821 (Cal. 1980) (recognizing "the universally accepted gravity of a false imputation of syphilis").

37. See Donovan, supra note 27 , at 1375.

38. A majority of states still follow the traditional physical injury rule; as of 1992, lowever, an "emerging (minority) trend" can be seen among the 14 states that have rejected the physical injury requirement. Marrs, supra note 30, at 4.

39. Heiner v. Moretuzzo, 652 N.E.2d 664, 665 (Ohio 1995).

40. Id. at 670 n.3 (citing, for exainple, Carney v. Knollwood Cemetery Ass'n., 514 N.E.2d 430, 432-33 (Ohio Ct. App. 1986) (permitting recovery where defendants were responsible for desecration of a grave)).

41. Id. at 670 . 
In reaching this holding, the Heiner court relied on Criswell $v$. Brentwood Hospital, ${ }^{42}$ in which the plaintiff's daughter was misdiagnosed as having been sexually abused. The Criswell court reasoned that "apprehension of a non-existent physical peril" does not warrant recovery. ${ }^{43}$ The court ultimately held that the physician who reported the abuse was immune from liability under state law. ${ }^{44}$ The plaintiffs claimed that immunity should not apply to einotional distress arising froin the misdiagnosis. However, instead of simply extending immunity, ${ }^{45}$ the court discussed at length the plaintiff's failure to fulfill the physical impact requirement. In doing so, the court departed from the traditional approacl in sucl cases, which is to protect the pliysician from liability without considering the issue of pliysical injury to the plaintiff. ${ }^{46}$ Like the HIV misdiagnosis cases, the physician in the Criswell case ordered tests to be administered, and did not perforin the tests himself. ${ }^{47}$ The physician simply reported what he believed to be the results of those tests. If he is privileged in reporting those results (whether correct or not) to the welfare authorities, it logically follows that he should be privileged in relaying that inforination to the family itself. In not taking this logical step to expand immunity, the Criswell court set an unnecessarily strong precedent for applying the plyysical impact rule in physician-patient cases of einotional distress.

The Heiner court's closing statement seeins a bit nore ambiguous than the Criswell loolding: "[w]hile we remain vigilant in our efforts to ensure an individual's 'right to einotional tranquility,' we decline to expand the law to permit recovery on the facts of this case." 48 This statement suggests either that the court was inaking the "individual's right to einotional tranquility"49 impossibly narrow, ${ }^{50}$ or that it meant to himit its own holding, protectimg a phy-

42. 551 N.E.2d 1315 (Ohio Ct. App. 1989).

43. Id. at 1318.

44. See id. at 1317.

45. The Criswell court based its finding of immunity on Ohio Revenue Code section 2151.421. See id.

46. See, eg., Michaels v. Gordon, 439 S.E.2d 722 (Ga. Ct. App. 1993) (holding psychologist immune from liability as long as his actions evince no bad faith).

47. See Criswell, 551 N.E.2d at 1316.

48. Heiner v. Moretuzzo, 652 N.E.2d 664, 670 (Ohio 1995) (citations omitted).

49. Id.

50. See generally Donovan, supra note 27, at 1354-55 (noting that several courts and legal scholars have condemned the physical imjury requirement as an under-inclusive 
sician who seems to have exercised reasonable care. Indeed, the outcome, summary judgment in favor of the defendants, does seem justified given the facts of the case. For example, the defendant physician had the blood tested twice, and immediately referred the plaintiff to a blood specialist. ${ }^{51}$ Nonetheless, the approach the court uses-requiring actual physical harm-is "outdated and ridiculous." $" 52$

In dissent, Judge Alice Robbie Resnick enıbraced a more appropriate approach. She noted that "some standards are necessary to govern recovery in a case such as this," but that "a blanket prohibition of recovery in false-positive cases is [not] appropriate. ${ }^{.53}$ She went on to argue that the "traditional tort law concepts of duty, breach of duty, proximate cause, and damages can serve to effectively limit recovery to those plaintiffs who deserve it, as in any other negligence case. ${ }^{.54}$ She emphasized that the requirement that the emotional harm be "serious" and that the damage be "foreseeable" provides a sufficient limit on the defendant's liability. ${ }^{55}$ Judge Resnick's dissent reproached the majority for its use of the physical imjury requirement. However, her belief in the effectiveness of the tort system as an effective limitation on recovery does not take into account the acute need for protection of the physician in cases involving new technology. ${ }^{56}$

Perliaps the Heiner court, like other state courts, felt constrained by precedent. For example, in R.J. v. Humana of Florida, Inc., the state District Court of Appeals for the Fifth District, in rejecting a neghigence claim based on an HIV misdiagnosis, stated: "Although we beheve that the [physical injury] rule should not apply to a case of a negligent HIV diagnosis, we acknowledge that this case does not squarely fall within the recognized exceptions to the impact rule and thus we are constrained to affirm the dismissal of the appellants' complaint.. ${ }^{357}$ The Supreme Court of Florida

screening device).

51. See Heiner, 652 N.E.2d at 665.

52. Amy L. Hansen, Establishing Uniformity in HIV-Fear Cases, 29 VAL. U. L. REv. 1251, 1269 (1995).

53. Heiner, 652 N.E.2d at $670-71$ (Resnick, J., dissenting).

54. Id. at 671 .

55. Id.

56. This need is evidenced by the reaction to the Pap smear cases. See infra notes 128-37 and accompanying text.

57. R.J. v. Humana of Florida, Inc., 625 So. 2d 116, 117 (Fla. Dist. Ct. App. 1993) (footnote omitted), affd in relevant part, 652 So. 2d 360 (Fla. 1995); see also Doe v. 
rejected the chance to make an exception to the impact rule for a neghigent HIV diagnosis: "were we to create such an exception," the court rationalized, "we would, of necessity, also be allowing a claim for emotional distress for any misdiagnosis made from negligent medical testing . . . . It would be exceedingly difficult to limit speculative claims for damages in hitigation under sucl an exception." 58

The Supreme Court of Florida noted that the outcoine of an HIV misdiagnosis suit miglt be different were the plaintiff able to demonstrate "imvasive medical treatment or prescriptions of caustic medication such as AZT, and that he suffered bodily imjury from that treatment"59- that is, if the plaintiff slowed a physical injury.

C. Fear-of Disease Cases: Models for Breaking Free of the Physical Injury Requirement

Courts who do reject the physical injury requirement continue to worry that emotional harm is often temporary and trivial, and may be easily falsified or imagined. There is concern that recovery is unfair because it imposes a disproportionately heavy financial burden upon the defendant, whose conduct was only neghigent. ${ }^{60}$ Most of the courts recognizing a duty to refram from negligent infliction of emotional distress also realize the need for weighing this duty against the interest in reasonably limiting the defendant's liability. Courts have limited recovery by raising the level of proof for proximate cause and ijjury, ${ }^{61}$ by using an objective standard regarding the reasonably foreseeable consequences of the defendant's negligence, ${ }^{62}$ or by limiting recovery to instances

Southeastern Univ., 732 F. Supp. 7 (D.C. 1990) (holding that a student alleging wrongful disclosure by defendant university that he had AIDS could not recover absent a physical injury).

58. R.J., 652 So. $2 \mathrm{~d}$ at 364.

59. Id. For a case following this rule, see Jones v. Department of Health \& Rehabilitative Servs., 661 So. 2d 1291, 1292 (Fla. Dist. Ct. App. 1995).

60. See, e.g., Payton v. Abbott Labs, 437 N.E.2d 171, 179 (Mass. 1982) ("[W] here the defendant's conduct has been merely negligent, without any element of intent to harm, his fault is not so great that he should be required to make good a purely mental disturbance.") (citation omitted).

61. See Donovan, supra note 27 , at 1370 .

62. See Dillon v. Legg, 441 P.2d 912, 919-21 (Cal. 1968) (holding that reasonable foreseeability defines the limits of the defendant's liability as well as the scope of the plaintiff's recovery). 
where a pre-existing duty exists. ${ }^{63}$ Concerns associated with allowing recovery for einotional distress are alleviated where fright and shock are "marked by definite physical symptoms," capable of medical or other objective proof, or where there is "some guarantee of genuineness in the circuinstances of the case." ${ }^{" 64}$

There is no general agreement among the courts as to what constitutes a "guarantee of genuineness." 65 The issue underlying this controversy is whether fairness will permit leaving the burden of loss upon an innocent plaintiff or, on the other hand, whether it is right to protect the plaintiff against mere neghigence, when the elements of extreme outrage and moral blane are lacking. ${ }^{66}$ Courts disagree as to the proper balancing of these concerns. In at least two situations courts have allowed damages for negligence in the absence of physical impact: the negligent mishandling of a corpse, ${ }^{67}$ and the neghigent transmission of a message, especially one announcing death. ${ }^{68}$ These two situations liave in common "an especial likelihood of genuine and serious mental distress, arising from the special circumstances, which serves as a guarantee that the claim is not spurious." ${ }^{29}$ Other situations, if any, that might constitute a similar guarantee have not been conclusively identified. However, if a message falsely reporting the death of a family inember is considered a guarantee that a plaintiff's suffering is genuine, then surely a message falsely predicting one's own death (such as misdiagnosis of HIV) is just as powerful a guarantee.

The need for a consistent approach to cases of neghigent infliction of emotional distress has become increasingly important in cases, like those concerning HIV misdiagnoses, involving disputed

63. See Donovan, supra note 27, at 1364-65.

64. W. Page KeEton et al., PROSSER and Keeton on the LAW OF TORTS $\$ 54$, at 361 (5th ed. 1984).

65. Id. (noting that one interest which is still a subject of substantial controversy is that of freedoin from mental disturbance).

66. See id. at 361; see, eg., Bamhill v. Davis, 300 N.W.2d 104, 109 (Iowa 1981) (Allbee, J., dissenting) ("I am not a party to the opening of this 'Pandora's Box.").

67. See, e.g., Gammon v. Osteopathic Hosp. of Me., Inc., 534 A.2d 1282, 1283, 1286 (Me. 1987) (allowing recovery for emotional distress against a hospital where plaintiff found a human leg in a bag purportedly containing his recently deceased father's personal belongings).

68. See, e.g., Johnson v. State, 334 N.E.2d 590, 592-93 (N.Y. 1975) (holding hospital liable for negligently informing the plaintiff that her mother had died, and noting that plaintiff suffered from "residual physical mamifestations" of her emotional distress).

69. KEETON ET AL., supra note 64 , at 362. 
medical technology. It has been noted that "[t]echnological disasters ... being of human manufacture, are at least in principle preventable, so there is always a story to tell about thein, always a moral to draw, always a share of blame to assign. They provoke outrage rather than acceptance or resignation." 70 This statement applies well to situations involving medical uncertainty. Patients subject to the inherent imperfections of new medical technology are understandably interested in finding a specific person to blame for their misdiagnoses. Courts must consider the imbalance between the individual's need to recover and the public interest in insulating critical new medical technology from hability.

One area in which courts have had to decide whether to allow emotional distress damages is the "fear of disease" cases. "Cancerphobia" and "AIDSphobia" cases usually involve a plaintiff who has allegedly been exposed to either disease and as a result suffers from a fear of having an increased risk of contracting that disease. Because of the deadly nature of cancer and AIDS, as well as the lack of education about the ways in which these diseases are contracted, "fear of disease" cases have been highly hitigated. Courts and commentators dealing with these cases have not taken a consistent approach in determining which claims are meritorious and should be hitigated. ${ }^{71}$ In the absence of clear medical proof of physical injury, courts generally hold that the plaintiff has the burden of deinonstrating some guarantee of genuineness of the alleged emotional harm, usually by the introduction of expert testimony ${ }^{72}$ to ensure the legitimacy of the claim. ${ }^{73}$

In most "fear of disease" cases, courts, refusing to break free of the physical injury requirement, inake the claim for emotional distress depend on the actual likelihood of the plaintiff developing the disease. ${ }^{74}$ Others have dismissed the physical injury require-

70. Donovan, supra note 27, at 1340 (quoting Kai Erikson, Toxic Reckoning: Business Faces a New Kind of Fear, HARV. BUS. REV., Jan.Feb. 1990, at 118, 125).

71. See Karen L. Chadwick, Fear of AIDS: The Catalyst for Expanding Judicial Recognition of a Duty to Prevent Emotional Distress Beyond Traditional Bounds, 25 N.M. L. REV. 143, 160-70 (1995).

72. See Donovan, supra note 27 , at 1394.

73. See Edward B. Lumpkin, Recovery of Emotional Distress Damages in AIDS-Phobia Cases: A Suggested Approach for Virginia, 51 WASH. \& LEE L. REV. 717, 742 (1994) (citing Marriott v. Sedco Forex Int'l Resources, Ltd., 827 F. Supp. 59, $75-76$ (D. Mass. 1993) (allowing recovery for emotional distress in AIDSphobia case under Jones Act because it was "beyond doubt that plaintiff suffered genuine emotional distress")).

74. See Jackson v. Johns-Manville Sales Corp., 781 F.2d 394, 411-12 (5th Cir. 1986). 
ment as unnecessary for proving the genuineness of the distress, and allow recovery even where there is only a "theoretical possibility" that the plaintiff's risk of fatal illness has increased..$^{75}$ One court justified its refusal to rely on the physical injury requirement by stating that the fear of cancer or AIDS "'must necessarily have a most depressing effect... [because like] the sword of Damocles, [the plaintiff] knows not when it will fall."'76

The "fear of disease" cases set an important precedent for HIV misdiagnosis cases, because at least a few of them properly reject the physical injury requirement, basing this decision on the generally accepted seriousness of cancer and AIDS.77 Thus, if courts are willing to allow recovery for the fear of future manifestation of a disease, they should certainly not balk at allowing recovery for the much inore tangible enotional distress in misdiagnosis cases. The enotional distress is more tangible in two significant ways. First, the "fear of disease" cases involve speculation about the reasonableness of the patient's fear, given that the disease itself is an unguaranteed future event. In contrast, in the case of a misdiagnosis, the fear has been completely realized when a person is told he is HIV-positive. Second, it is often difficult to restrict the "fear of disease" cases to a specific time period, ${ }^{78}$ whereas a misdiagnosis and subsequent negative test are easily isolated in time.

In rejecting the physical injury test, some courts express the legitimate concern that "fear of disease" cases discourage physicians from warning patients about possible complications (such as exposure to cancer or AIDS) involved in surgery or treatınent. ${ }^{79}$

75. See Gilliam v. Roche Biomedical Labs., Inc., 989 F.2d 278, 279-80 (8th Cir. 1993) (allowing damages for fear of future cancer even though medical testimony established that there was only a "theoretical possibility" that the delay in the patient's treatment could cause her cancer to become invasive in the future).

76. Glen Donath, Curing Cancerphobia Phobia: Reasonableness Redefined, 62 U. CHI. L. REV. 1113, 1114-15 (1995) (quoting Alley v. Charlotte Pipe \& Foundry Co., 74 S.E. 885, 886 (N.C. 1912)).

77. See, e.g., Marriott, 827 F. Supp. at 75-76 (allowing recovery for emotional distress in AIDS-phobia case because it was beyond a doubt that the plaintiff suffered genuine emotional distress).

78. Courts usually attempt to limit recovery to a "reasonable window of anxiety," typically the time from which the plaintiff is exposed to the disease to the time at which the plaintiff learns that she does not have the disease. See, e.g., Faya v. Almaraz, 620 A.2d 327, 337 (Md. 1993). Often, however, exposure is not instantaneous but gradual, as when an employee is exposed to asbestos in the workplace. See, e.g., In re Hawain Federal Asbestos Cases, 734 F. Supp. 1563 (D. Haw. 1990).

79. See, e.g., Howard v. Mount Sinai Hosp., Inc. 219 N.W.2d 576, 577 (Wis. 1974) 
Unfortunately, despite their concern for the physicians, a number of these courts hold that the "pre-existing relationship" estabhished by the physician-patient interaction establishes a duty on the part of the physician to avoid any infliction of emotional distress. ${ }^{80}$ Thus, while the "fear of disease" cases rightly reject the physical mjury test, they embrace a test that is at least as problematic.

\section{The Dangers of EXPANDING Physician Liability}

\section{A. The Physician-Patient Relationship as a Basis for Emotional Distress Liability}

Since the 1980s, courts have increasingly used the physicianpatient relationship as a basis for a cause of action for emotional distress. ${ }^{81}$ One commentator has argued:

It does not strain one's credulity to recognize that the doctorpatient relationship imposes an obligation on the part of the doctor to use care both in the treatment and diagnosis of a patient. Neither is it an illogical extension of existing law to say that duties arising out of a fiduciary relationship include the duty to prevent einotional harm in the course of performing the obligations imposed by the [doctor-patient] relationship. ${ }^{82}$

Basing the recovery for emotional distress on the physician-patient relationship sets a dangerous precedent in the HIV misdiagnosis cases because it detracts attention from two important considerations. First, it blurs the distinction between physician negligence and the inherent faultiness of the medical technology involved. Second, it focuses attention on the physician's duty to his patient and ignores his duty to the public health. ${ }^{83}$

(stating that "to allow recovery would be contrary to public policy" and put "too unreasonable a burden upon doctors and physicians").

80. See infra notes $81-88$.

81. See generally Chadwick, supra note 71 , at 149 "In the 1980 s, there was a gradual expansion of recovery for negligently inflicted emotional distress where the victim was able to prove a preexisting relationship with the tortfeasor at the time of the emotional injury.").

82. Id. at 159 .

83. For a discussion of a physician's duty to protect public health, see Marc A. Rodwin, Strains in the Fiduciary Metaphor: Divided Physician Loyalties and Obligations in a Changing Health Care System 21 AM. J.L. \& MED. 241, 250-51 (1995) (noting that in addition to the plysician's duty to her patient, she has a "role in promoting public health"); see also infra notes 91-96 and accompanying text. 
Physicians have also faced increased hability because the tendency of courts to be deferential to a physician's judgment seems to be declining. ${ }^{84}$ The combination of increased emphasis on the physician-patient relationship and decreased deference to medical judgment not only leaves physicians fully exposed to the arbitrariness of the tort system, but bases their hability upon their very role as a physician. This may make sense in a typical case of physician negligence; it is undesirable to cloak negligent behavior in deference. Where the "negligence" is the result of imperfect medical technology, however, it is equally undesirable that a physician be held responsible for mistakes that he did not make.

\section{B. Liability to Third Parties}

A second danger in doing away with the check provided by the physical injury requirement is that the physician-patient relationship may lead to physicians' broad hability to third parties. Because courts have recognized that the physician is the first line of defense against the spread of communicable diseases, ${ }^{85}$ they hold that the duty of a physician extends to those "within the foreseeable orbit of risk of lrarm" presented by the patient. ${ }^{86}$ Whenever a physician is placed in a position where the absence of ordinary care and skill would cause danger of injury to a third

84. See, eg., David HaRney, MEdical MalPRACTiCE, §§ 16.3, 21.6 (1994). There has been a recent decline in the use of the California Book of Approved Jury Instructions, section 6.02, entitled "Medical Perfection Not Required," which states: "A physician is not necessarily negligent because [she] errs in judgenent or because [her] efforts prove unsuccessful. The physician is negligent if the error in judgement or lack of success is due to a failure to perform any of the duties as defined by these instructions." See THE COMMITTEE ON STANDARD JURY INSTRUCTIONS, BOOK OF APPROVED JURY INSTRUCTTONS (BAI), (8th ed. 1995); see also Riggins v. Mauriello, 603 A.2d 827, 831 (Del. 1992) (noting an even spht between states upholding the instruction and those deciding it is prejudicial to the plaintiff).

85. See, e.g., Jones v. Stanko, 160 N.E. 456,458 (Ohio 1928) (holding that a physician caring for a patient with a contagious or infectious disease has a duty to exercise care in advising and warning members of the family and to avoid doing any act which would tend to spread the infection, and to take all necessary precautionary measures to prevent its spread to other patients); 41 AM. JUR. 2d Physicians \& Surgeons, § 246 (1995) (stating that one "who by reason of his professional relations is placed in a position where it becomes his duty to exercise ordinary care to protect others from injury or danger is liable in damages to those injured by reason of his failure to do so").

86. DiMarco v. Lynch Homes-Chester County, Inc., 583 A.2d 422, 424 ( $\mathrm{Pa} .1990)$ (quoting Doyle v. South Pittsburgh Water Co., 199 A.2d 875, 878 (Pa. 1964)). 
party, a duty arises to use ordinary care to avoid that danger. ${ }^{87}$ These courts reason that the special relationship between a patient and his doctor or psychotherapist gives rise to affirmative duties to third parties. ${ }^{88}$ The doctor must balance the duty to her patient against her duty to protect public health; that is, sle must weigh the utility of the doctor's publicizing a patient's condition against the harm to an individual patient caused by the doctor's publication. ${ }^{89}$ Thus, if a physician's informing a third party of a patient's disease should be fully protected, then the physician should not be leld negligent im inflicting harm on his patient by informing a third party.

In the case of HIV misdiagnosis, the physician's duty to prevent emotional harm to her patient (which might lead a physician to avoid reporting positive ELISA tests) conflicts with her duty to protect society from contagious disease (which would influence the physician to disclose positive ELISA test results as soon as possible). The balancing is complicated by the slight uncertainty of the ELISA test's results. And because of the social stigma surrounding HIV, misdiagnosed patients are particularly sensitive to disclosure of HIV-positive status. ${ }^{90}$ Thus, courts have the difficult task of weighing the "physician's role in promoting public health" and controlling the spread of disease ${ }^{11}$ against the concern for avoiding the creation of genuine emotional distress in individual patients.

87. See, e.g., Tarasoff v. Regents of Univ. of Cal., 551 P.2d 334, 343-44 (Cal. 1976).

88. Id. at $342-43$ (holding that departure from this "fundamental principle" is only justified after weighing such factors as: foreseeability and certainty of the harm's occurring, causal connection, moral blame, policy of preventing future harm, and the consequences to the community of imposing a duty on the physician).

89. In Moning v. Alfono, the court, in discussing whether to hold a producer of slingshots liable for an injury caused by one of its products, explained:

The reasonableness of the risk of harm ... tums on low the utility of the defendant's conduct is viewed in relation to the magnitude of the risk. If a court is of the opinion that marketing slingshots directly to children is of such utility that it should be fully protected, the court in effect determines as a matter of law that the risk of harm so created is not unreasonable and, therefore, such conduct is not negligent.

254 N.W.2d 759, 762 (Mich. 1977).

90. See, e.g., Chadwick, supra note 71, at nn.132-35 and accompanying text. Studies have indicated that males who have disclosed their HIV status show significantly higher suicide rates than other males in their age group. See Mary Anne Bobinski, Risk and Rationality: The Centers for Disease Control and the Regulation of HW-infected Health Care Workers 36 ST. LouIs L.J. 213, 294-95 (1991) (citing Marzuk et al., Increased Risk of Suicide in Persons with AIDS, 259 JAMA 1333 (1988)).

91. Rodwin, supra note 83 , at 252. 
Traditionally; courts have favored the physician's right to disclosure over the patient's right to privacy, even in cases involving stigmatic diseases. Several cases stress that the physician has a positive duty to protect third parties from a patient's communicable disease. For example, in DiMarco v. Lynch Homes-Chester County, Inc., a patient's sexual partner contracted hepatitis from the patient, and then brought an action agamst the patient's physician. ${ }^{92}$ The court held that if the third person plaintiff was in the class of persons whose health was likely to be threatened by a patient with a communicable disease, and if erroneous advice is given to that patient by the physician to the ultimate detriment of the third person, the third person has a cause of action against the physician. ${ }^{93}$ The court determined that the physician was negligent not to have warned the patient to discontinue sexual relations. ${ }^{94}$ Many courts, as in DiMarco, hold that a physician has a duty to protect public health, and that a physician should presunie the existence of a third party in the case of communicable diseases. ${ }^{95}$ They note that a physician should take an active role in preventing the spread of such diseases. ${ }^{96}$

Failure to warn third parties has been extended to cases involving misdiagnoses. ${ }^{97}$ In Molien v. Kaiser Foundation Hospi-

92. 583 A.2d 422, 423 ( $\mathrm{Pa} .1990)$.

93. Id. at 423.

94. The Restatement (Second) of Torts states:

One who undertakes .... to render services to another which he should recognize as necessary for the protection of a third person .... is subject to liability to the third person for [the] physical harm resulting ... [if] his failure to exercise reasonable care increases the risk of such harm, or ... harm is suffered because of reliance of the other or the third person upon the undertaking.

RESTATEMENT (SECOND) OF TORTS $§ 324(A)$ (1977).

95. See, e.g., Gooden v. Tips, 651 S.W.2d 364 (Tex. Ct. App. 1983); see also infra notes $98-100$ and accompanying text.

96. But see Lemon v. Stewart, 682 A.2d 1177 (Md. Ct. Spec. App. 1996) (holding that when a patient is diagnosed as positive for HIV or AIDS, the physician has no duty to inform members of the patient's family, and that third parties do not have a cause of action against the physician for failing to do so); Ordway v. County of Suffolk, 583 N.Y.S.2d 1014, 1017 (N.Y. Sup. Ct. 1992) (holding, in an AIDSphobia case, that the county's duty was to protect the confidentiality of arrestee's HIV status, not to impart such knowledge to arrestee's surgeon).

97. See Robert J. Liebovich, Comment, 24 MEMPHIS ST. U. L. REV. 377, 377-79 (1994) (describing a case in which a physician was held negligent for his failure to warn a family about the contagious nature of Rocky Mountain Spotted Fever). Some courts have tried to limit this liability, issisting that the physician must be aware of the specific risks to specific persons before a duty to warn exists. See, e.g., Gammill v. U.S., 727 F.2d 950, 954 (10th Cir. 1984) (holding that a physician has a duty to exercise reasonable care 
tals, ${ }^{98}$ a California court held a physician liable to a third party suffering emotional distress, stating that where a defendant physician should have foreseen emotional harm to the third party, she will be held liable. ${ }^{99}$ In Kaiser, the defendant physician misdiagnosed a woman as having infectious syphilis. When the patient's husband sued for emotional distress, the court allowed damages: "[i]t is easily predictable," the court reasoned, "that an erroneous diagnosis of syphilis and its probable source would produce marital discord and resultant emotional distress to a married patient's spouse; ... . under these circumstances[,] defendants owed plaintiff a duty to exercise due care $\mathrm{m}$ diagnosing the physical condition of his wife." 100

Holding a physician liable to third parties for misdiagnosing patients may have dangerous consequences, especially in cases involving new technology. The professional service is not perforned for the third party, the physician may not even know of the existence of the third party, and there is neither privity nor a specific undertaking in favor of the third party. As a result of exposure to sucl unpredictable hability, a physician may be less willing to use new technology. ${ }^{101}$

Despite the social stigma of AIDS, courts have held that an HIV-positive test is no more exenpt from disclosure than any other disease that threatens the well-being of third parties. In one AIDSphobia case, a hospital failed to warn a police officer that the patient whom he was asked to subdue suffered from AIDS. ${ }^{102}$ The officer was bitten by the AIDS patient and brought an action against the hospital for emotional distress. The court held that the officer could recover because the public policy concerning confidentiality of patients' records did not limit the hospital's duty to warn the officer. ${ }^{103}$

to prevent spread of infectious disease only to patient's family).

98. 616 P.2d 813 (Cal. 1980).

99. See id. at 817.

100. Id. The court also rejected the physical injury requirement:

In our view[,] the attempted distinction between physical and psychological injury merely clouds the issue. The essential question is one of proof; whether the plaintiff has suffered a serious and compensable injury should not turn on this artificial and often arbitrary classification scheme ... in the light of contemporary knowledge we conclude that emotional injury may be fully as severe and debilitating as physical harm, and is no less deserving of redress.

Id. at 814,821 .

101. See infra notes 128-37 and accompanying text.

102. See Johnson v. West Va. Univ. Hosps., 413 S.E.2d 889, 891 (W.Va. 1991).

103. See id. at 895 (citing a West Virginia act specifically referring to AIDS testing, 
By recognizing this duty to prevent physical as well as mental harm to third parties, courts create a situation in which physicians must be constantly aware of the effects of their actions on parties beyond the privity of the physician-patient relationship. ${ }^{104}$ Given that physician hability to third parties is generally recognized, ${ }^{105}$ physicians who behieve that their patients are HIV-positive may feel it necessary to inform third parties as well as their patient, in order to prevent the spread of AIDS. Allowing recovery to third parties is overly burdensome to physicians. Its assignment of hability may contribute to rising medical insurance costs and also to physicians' decisions to cease practice due to hability concerns. ${ }^{106}$ In the absence of the check provided by the physical injury requirement, even minute numbers of misdiagnoses leading to large jury verdicts for the patient or a third party seriously threaten physicians and may seriously hinder the availability of imovative care.

In the wake of HIV misdiagnosis cases in which plaintiffs have received large damage awards, ${ }^{107}$ physicians are unfairly faced with the decision of whether to divulge HIV test results to third parties and prevent the spread of disease, or to withhold such knowledge as long as possible from both the patient and third parties to prevent the possibility of being sued for a misdiagnosis. The dangerous consequences of forcing physicians to choose

the AIDS Related Medical Testing and Records Confidentiality Act, W. VA. CODE $\S 16-3 C-3(a)(4)(1988)$ ). The court based its decision on the emotional distress of the plaintiff, without requiring an accompanying physical injury. The court held that the wound from the bite, sleeplessness, and loss of appetite were sufficient. Id. at 896 .

Along with Johnson, consider the cases in which the physician is diagnosed as HIV-positive. At least one commentator argues that a physician's HIV-positive status "should not, in and of itself, provide a patient with a cause of action against the [physician]." Dorothea Beane, AIDS Crisis and the Health Care Community: Public Concerns Triggering Questionable Private Rights of Action for Emotional Harms and Legislative Response, 45 MERCER L. REV. 633, 636 (1994).

104. See, e.g., Chizmar v. Mackie, 896 P.2d 196, 213 (Alaska 1995) (holding that physician's false positive diagnosis of plaintiff could provide basis for loss of parental consortium claim on behalf of plaintiff's children when false diagnosis, based on screening test, purportedly led to divorce).

105. See id. at 202-03.

106. See Jonathan J. Frankel, Note, Medical Malpractice Law and Health Care Cost Containment: Lessons for Reformers from the Clash of Cultures, 103 YALE L.J. 1297, 1298 (1994).

107. See, e.g., Machesney v. Bruni, 905 F. Supp. 1122, 1131 (D.D.C. 1995) (reducing four million dollar jury award to two million in case of false positive diagnosis and subsequent treatinent). 
between disclosure and caution are aptly illustrated in the recovered memory therapy cases.

\section{Examples of the Consequences of Expanded Physician Liability}

1. Recovered Memory Therapy. The well-publicized recovered memory therapy cases demonstrate the consequences of broad physician liability to third parties in a situation that, like HIV misdiagnosis cases, involves uncertain medical knowledge. Recovered memory therapy cases liave typically involved an adult daugliter, who, througli the help of a psychologist, "recovers" repressed meinories of childhood abuse by her father. ${ }^{108}$ The technique involves the use of leading questions and other aggressive memory-enhancing procedures to help patients remember events that were so traumatic that their minds had repressed them. ${ }^{109}$ Some therapists who specialize in treating victims of incest and rape rely heavily on recovered memory techniques. ${ }^{110}$

Cases involving misdiagnoses of sexual abuse are typically weighted in favor of encouraging the physician to disclose to an autliority any possibility of abuse of her patient. ${ }^{111}$ This traditional protection for the physician was upheld in a recent case, Bird $v$. W.C.W. ${ }^{112}$ In Bird, a father, cleared of charges of child abuse, brought a neghigence action against the psychologist who liad misdiagnosed his child. The court lield that the psychologist owed no duty not to misdiagnose the child, noting that psychology is an "inexact science."

108. See Victor Dricks, False 'Memories' of Sexual Abuse Rip Families Apart: 'Syndrome' Sparks Heated Debate, PHOENIX GAZETTE, Mar. 25, 1993, at A1, A8.

109. See, e.g., Hollida Wakefield \& Ralph Underwager, Recovered Memories of Alleged Sexual Abuse: Lawsuits Against Parents, 10 BEHAVIORAL SCIENCE \& LAW 483, 490 (1992) (noting that childhood sexual abuse victims are more prone than the general public to suicidal thoughts, alcohol and drug abuse, anorexia, and bulimia).

110. See, e.g., Miriam Horn, Memories Lost and Found, U.S. NEWS \& WORLD REP., Nov. 29, 1993, at 52, 54 (stating that it is generally agreed that victims of childhood sexual abuse can repress recollections of what happened to them, and that those memories can be loosened years later, and that highly regarded psychologists and psychiatrists consider recovered memory therapy a significant benefit for victims who have repressed memories of incest).

111. For a case discussing physician hability, see Metzger v. Sebek, 892 S.W.2d 20, 41 (Tex. App. 1994) (holding that mental health care professional owed no professional duty to father not to negligently misdiagnose the condition of his child and finding that in Texas, there is no longer a cause of action for negligent infliction of emotional distress).

112. 868 S.W.2d 767 (Tex. 1994).

113. Id. at 769 . 
extended plyysician liability to third parties suffering emotional distress, the Bird court determined that foreseeability of harm to the parents could not be a basis for recovery. ${ }^{114}$ Other courts have taken Bird one step further, holding that a psychologist has an affirmative duty to disclose certain information to third parties. ${ }^{115}$ The cases turn, as do the HIV misdiagnosis cases, on whether the court decides that the utility of disclosure outweighs, for policy reasons, the chance of a misdiagnosis negatively affecting one of the parties involved.

Recovered memory therapy adds a new twist to cases dealing with a therapist's duty to report child abuse, making them even nore akin to the HIV misdiagnosis cases. The twist arises from the inedical uncertainty surrounding recovered meinory therapy. ${ }^{116}$ Some experts contend that recovered meinory therapy has only a "pseudoscientific" foundation, ${ }^{117}$ and that no empirical scientific evidence supports the theory that a person can lose a inemory for many years and then accurately recover it. ${ }^{118}$ At least one social psychologist believes that recovered meinory therapy "will come to be recognized as the quackery of the 20th century." 119 On the other hand, recovered inemory therapy is support-

114. See Bird, 868 S.W.2d at 769; cf. Hite v. Brown 654 N.E.2d 452, 458-59 (Ohio App. 1995) (holding that psychologist who failed to report child abuse is not liable because psychologist's duty to report does not extend beyond psychologist-patient relationship).

115. See, e.g., Montoya v. Bebensee, 761 P.2d 285, 288-89 (Colo. Ct. App. 1988).

116. The recent popularization of the incest survivors movement, see Elizabeth $P$. Loftus, The Reality of Repressed Memories, 48 AM. Psychologist 518, 523 (1993), has had a detrimental impact on expert opinions of recovered memory therapy. See, e.g., ELLEN Bass \& LAURA Davis, THE Courage to HEAL (1988). This controversial best-selling book has been referred to as the "bible" of the mcest survivors movement, and has contributed to the recent surge in the popularity of recovered memory therapy. The book has been criticized for its repeated suggestions that "abuse probably happened, even if one has no memories of it," the book's statements that "demands for corroboration of abuse are not reasonable," and the book's encouragement of "revenge, anger, fantasies of murder or castration, and deathbed confrontations." Christina Bannon, Comment, Recovered Memories of Childhood Sexual Abuse: Should the Courts Get Involved When Mental Health Professionals Disagree? 26 ARIZ. ST. L.J. 835, 838 (1994) (citations omitted). In response to the lawsuits brought by adult children, parents who clain to have been wrongfully accused have established a "False Memory Syndrome Foundation." See Stephanie Salter \& Carol Ness, Critics Denounce False-Memory Group, S.F. EXAMINER, Dec. 27, 1993, at A1.

117. See John Hochman, Pseudo-Therapists Cultivate 'Recovered Memory' Accusations, S.F. EXAMINER, Dec. 16, 1993, at A23.

118. See Bannon, supra note 116 , at 845 .

119. Id. at 846 (quoting Richard Ofshe, social psychologist at the University of Cali- 
ed by respected experts in psychology. ${ }^{120}$ Thus, the issue becomes whether a therapist's use of recovered memory therapy should trigger the traditional Bird protection against liability for third party emotional distress.

Over this battlefield of contradictory approaches, cases have been brought by all the parties involved: by daughters against their fathers, by daughters who retract charges of sexual abuse and bring suits against their therapists for implantation of false memories of abuse, by fathers against therapists for emotional distress arising out of the charge of child abuse. ${ }^{121}$ The inost common claims asserted in cases against therapists are the breach of a duty of due care, negligence and medical inalpractice. ${ }^{122}$ Typically, in order for the parent (or the adult child) to demonstrate a therapist's malpractice, the parent must show that the therapist failed to exercise the degree of care, skill and learning expected of a reasonable health care provider in the saine profession and acting under similar circumstances. ${ }^{123}$

In a recent well-publicized case, Gary Rainona, who had been accused of molesting his daughter, contended that a psychotherapist had manipulated his adult daughter into remembering childhood incidents of incest that he said never occurred. ${ }^{124}$ The jury awarded $\$ 500,000$ to Ramona to compensate for his enotional distress, thus publicizing the belief that recovered memory therapy is

fornia, Berkeley).

120. See, e.g., Horn, supra note 110, at 54-55 (quoting Yale University Professor Michael Davis explaining that traumatic events "produce unusually strong nerve connections that serve as long-lasting memories" which can be triggered years later by the right stimulus).

121. See Loftus, supra note 116 , at 522 (discussing a case in which a large sum was awarded to the adult victim).

122. See, e.g., Hubbard v. Laurelwood Hosp., 620 N.E.2d 895, 896 (Ohio Ct. App. 1993) (alleging that failure to admit suicidal decedent as psychiatric patient constituted a breach of the duty of due care and medical malpractice); Smith v. Pust, $23 \mathrm{Cal}$. Rptr. $2 \mathrm{~d}$ 364, 367 (Cal. Ct. App. 1993) (claiming negligence by therapist who had sexual encounter with patient while counseling her about childhood sexual abuse); Montoya v. Bebensee, 761 P.2d 285, 286 (Colo. Ct. App. 1988) (alleging that the therapist was negligent in accusing father of sexually abusing his child); Gordon v. Milwaukee County, 370 N.W.2d 803, 804 (Wis. Ct. App. 1985) (alleging that the county was negligent in releasing decedent when it knew he was suicidal).

123. See Bannon, supra note 116 , at $851-52$ (citing as an example of this requirement the Arizona Revised Statutes $\$ 12-563(\mathrm{~A})$ ).

124. See B. Drummond Ayres Jr., Jury Awards Father Accused of Incest In Memory Therapy, N.Y. TIMES, May 14, 1994, at A1. Ramona tried to prove that his daughter's therapists had planted memories of abuse using the imfluence of a hypnotic drug. See id. 
a loax. ${ }^{125}$ This example of broad therapist liability to a non-patient third party suggests the possible chilling effect of allowing a court (in this case a jury) to decide an issue involving controversial medical technology.

One commentator lias noted that "until mental health professionals reacl an agreement regarding the validity and reliability of memory recovery techniques, courts have no choice but to allow juries to decide the validity of meinory recovery therapy as a question of fact in eacli case," an approach which leads to "imconsistent jury verdicts and uncertainty regarding a therapist's potential hability." ${ }^{\prime 26}$ To the extent that recovered memory therapy is a valid and useful medical tool, verdicts agaimst therapists indicate that juries are more swayed by individual pleas than by overarching public policy considerations. If recovered memory therapy is viewed as dainaging the parent-child relationship, cases like Ramona "would lead to more suits like it," 127 brought by parents and other non-patients who are affected by therapists' treatment. Given that recovered memory therapy is supported by at least soine experts, it seems undesirable to give the tools to eradicate it to an uninformed court or jury.

A physician's unchecked liability to patients and non-patient third parties raises the question of the consequences of such liability. In areas such as recovered memory therapy or HIV testimg, a physician's liability is in danger of being equated with the uncertainties of developing, imperfect medical technology. This second danger of doing away with the plysical injury requirenent is illustrated by the "Pap smear" cancer misdiagnoses.

2. Pap Smear Testing. Recent lawsuits involving the "Pap smear" test-used to diagnose cervical cancer in women-clearly demonstrate that the prospect of liability for misdiagnoses threatens not only physicians but medical technology itself. ${ }^{128}$ Millions of women take the Pap sinear test every year, and despite the fact that the test is "one of the greatest success stories in the history of medicime in terms of cancer prevention," 129 thousands

125. See id.

126. Bannon, supra note 116 , at 855 .

127. Mark Hansen, More False Memory Suits Likely, A.B.A. J., Aug. 1994, at 36, 37.

128. See, e.g., Gangemi v. National Health Labs., 677 A.2d 1163 (N.J. Super. 1996); Allenius v. Thomas, 538 N.E.2d 93 (Ohio 1989).

129. Katherine M. Bayliss \& Debra Van Eyck, At This Rate, Pap Smear May Be 
of women are misdiagnosed. ${ }^{130}$ These misreadings have led to cervical cancer going undetected and, in some cases, patient deaths. In a recent case, a Milwaukee medical lab was charged with reckless homicide in the deaths of two women whose Pap smears were allegedly misread. ${ }^{131}$ The general counsel of the American Medical Association criticized the bringing of this criminal case: "There have to be penalties, and there are penalties, for physicians and others who make mistakes. There are some severe ones, but to move into the criminal system is just going to make physicians even nore defensive and less aggressive, and we don't want a doctor who's afraid to see patients."132 Others hope that the case will not deter women from having regular checkups and Pap smears, because "while there are cases of human error in the medical field, and while the tests are not one hundred percent reliable, they are the best [available], and ... have greatly reduced the number of women who have died of cervical cancer." $" 133$

There has been mounting concern regarding the fate of the Pap smear test in the face of the increasing numbers of cases like the one in Milwaukee. Experts worry that given the publicity of these misdiagnoses, the public has been misinforined, resulting in an "unfortunate disservice to society." cate a common assumption that when a woman suffers from cervical cancer following a negative Pap sinear test, malpractice must have occurred, even though (as in the case of the ELISA test) misdiagnoses may be due entirely to the "inherent limitations" of

Nearing Extinction: Litigation and Misinformation Threaten Availability of This Important Screening Technique for Women, MILWAUKeE JouRnAl SENTINEL, Apr. 18, 1995, at A7. Cervical cancer deaths have declined $65 \%$ in the past thirty years. Id.

130. Unlike the HIV misdiagnoses, the mistake in the Pap sinear cases arises from false negatives rather than false positives. In this way, the Pap smear misdiagnoses would generally lead to serious physical harm, rather than the emotional harm involved in an HIV false positive case. Indeed, most cases are brought as suits for wrongful death. See Edmonds v. Cytology Servs. of Md. Inc., 681 A.2d 546 (Md. Ct. Spec. App. 1996); Gangemi, 677 A.2d 1163; Allenius, 538 N.E.2d 93.

131. This case involves charges against tests that were made before the federal government enacted new standards in the early 1990s, limiting the number of slides technicians could read in a given period of time. See Morning Edition: Misreading of Pap Smears Results in Homicide Charges, (National Public Radio, broadcast Apr. 13, 1995), available in 1995 WL 2958048.

132. Id.

133. Id.

134. Bayhiss \& Van Eyck, supra note 129, at A7. 
the Pap smear test itself. Fear among cytotechnologists and pathologists regarding the increased number of lawsuits will most likely decrease the availability of the Pap sinear and increase costs of the test. ${ }^{135}$ One expert has asked, when considering the big picture, "does successful prosecution of [these cases] at this point in time benefit society in any way? Can this possibly outweigh the continued damage done to what was a readily available, inexpensive and life-saving screening technique?"136

Though there are indications that Pap smear technology is improving, ${ }^{137}$ the fear engendered in the medical profession as a result of the suits brought against them demonstrates the power that courts possess over the fate of uncertain medical technology. Courts should carefully consider whether the imterests of an individual patient, whose misdiagnosis was due to the inherent imperfections of a medical test, outweigh society's interest im making such tests available.

\section{Moving Beyond the Physical Injury Rule: Chizmar v. Mackie}

The court in Heiner v. Moretuzzo described "serious emotional distress" as an "emotional injury which is both severe and debilitating." 138 Thus, serious emotional distress may be found where a reasonable person, nornally constituted, would be "unable to cope adequately with the mental distress engendered by the circumstances of the case."139 In Chizmar v. Mackie ${ }^{140}$ the Supreme Court of Alaska also utilized this "reasonable person" approach.

In Chizmar, the plaintiff brought a claim for negligent infliction of einotional distress against her physician both for neghigently misdiagnosing her as HIV-positive and for negligently misreporting

\section{See id.}

136. Id.

137. An advisory committee of the Food and Drug Administration has recommended government approval of two computer-based systems for use in double-checking Pap smears. Dr. G. Frederick Kessler, director of labs for Aurora Health Care, said: "'This system protects us against potential litigation, it provides the cytotechnologist with added confidence that they have screened everything on the slide ...." Ronald Rosenburg, Backing Up a Test for Cancer Cambridge Firm Finds a Way to Cut Misreading of the Cervical Pap Smear, Boston GloBe, Sept. 10, 1995, at A69 (quoting Dr. Kessler).

138. 652 N.E.2d 664, 667 (Ohio 1995).

139. Id. (quoting Paugh v. Hanks, 451 N.E.2d 759, 759 (Ohio 1983)).

140. 896 P.2d 196 (Alaska 1995). 
the results to her husband. The court, ignoring the physical injury rule, held that a physician has a duty to refrain from inflicting emotional distress on her patient. ${ }^{141}$ In addition, the court held that a physician is privileged to disclose reports to the patient's spouse and that the physician could not be held liable for the patient's enotional distress caused by this reporting. ${ }^{142}$ Thus, Chizmar, while moving beyond the physical imjury requirement, raises two issues: first, whether, in a case involving new medical techniques, it is safe to leave a physician's hability up to a jury; and second, whether, in the absence of the physical injury requirement, a physician's duty to a third party may lead to unchecked hability.

The court held that the defendant physician owed his patient a duty to refrain from activity that presented a foreseeable and unreasonable risk of causing emotional distress, ${ }^{143}$ and remanded the issue of negligent misdiagnosis for presentation to the jury. ${ }^{144}$ The Chizmar court believed that the "reasonable" people in the jury would be an adequate check on limitless hability. ${ }^{145}$

The court also held that when a physician has diagnosed a patient with a fatal, sexually transmitted disease, he is privileged to disclose the diagnosis (whether correct or not) to the patient's spouse. ${ }^{146}$ Thus, the patient's claim for emotional distress arising from the physician's breach of duty of confidentiality was foreclosed as a matter of law. The court did not recognize the inconsistency of, on the one hand, fully protecting the physician's disclosure of the diagnosis to the plaintiff's spouse, and on the other, subjecting his disclosure to the plaintiff to full liability.

In addressing Chizmar, the court also responded specifically to the appellate court's decision to apply the physical injury requirement. Wisely throwing out the lower court's rehance on that requirement, ${ }^{147}$ the court overcompensated by allowing the plaintiff's claims to be remanded to the jury without any limit placed on the liability of the defendant physician. Thus, the Chizmar court broke free from the physical mjury precedent, but

141. See id. at 203.

142. See id. at 208.

143. See id. at 203.

144. See id. at 205.

145. See id.

146. See id. at 208.

147. See id. at 200-03. 
failed to replace the physical injury requirement with some meaningful limitation on physician liability.

\section{Protecting Physicians with a PROFESSIONAL JUDGMENT RULE}

It is clear that the physical impact requirement is no longer a legitimate means of limiting plaintiff recovery where HIV misdiagnoses are concerned. As an attorney for the misdiagnosed patient in Jones $v$. Department of Health \& Rehabilitation Services ${ }^{148}$ pointed out: "The legal system does not keep pace with society . . . U Up until 1986 or so, AIDS didn't exist. Are we going to do an injustice to a few people to guard against the problem of fraudulent claims down the road?"149 The court in Jones relied on the finding in R.J. v. Humana of Florida, Inc. that the exception to the physical impact rule would have a "substantial impact on inany aspects of medical care, including the cost of providing that care to the public."150 Were it to create such an exception, the $R . J$. court continued, it would, of necessity, also be allowing a claim for einotional distress for "any misdiagnosis made from negligent medical testing." 151 The $R . J$. court concluded that it would be exceedingly difficult to limit speculative claims for damages in litigation. ${ }^{152}$ Given the effect that negative media might lave on uncertain medical techniques such as Pap smear tests, and given the awkward position of a juror in weighing a visible and emotionally suffering individual against the less immediate societal interest in preventing spread of a disease or in preventing child abuse (as in recovered memory therapy), courts need to protect the physician administering HIV tests against the arbitrary results of an unlimited tort system.

To protect recovered meinory therapy, the Pap smear test, and the ELISA test, courts must protect the physicians who provide such treatinent. When specific medical techniques are imperfect or standards are unclear, courts should, instead of following the lead of the recovered memory cases, apply a good faith immu-

148. 661 So. 2d 1291 (Fla. Dist. Ct. App. 1995).

149. Mike Oliver, Top Court's 'Impact Rule' Bars Relief For Mental Anguish of HIV Misdiagnosis, ORLANDO SENTINEL, Apr. 5, 1995, at A10.

150. 652 So. 2d 360, 363-64 (Fla. 1995).

151. Id.

152. See id. 
nity standard in order to determine whether the defendant has breached a duty. Liability should arise only in where the treating physician does not act in good faith or fails to exercise professional judgment. This standard would recognize that some modern medical technology is "very difficult to administer."153 Along these lines, courts have held that a mental health provider who uses proper therapeutic procedures may not be found negligent, even if the ultimate diagnosis is incorrect. ${ }^{154}$

There have been a number of legislative responses to the physician's duty to third parties in HIV cases. For example, the California Health and Safety Code provides: "No physician has a duty to notify any person of the fact that a patient is reasonably believed to be infected by the probable causative agent of acquired immune deficiency syndrome." 155 The Code also provides that no physician shall be held liable for "disclosing to a person reasonably believed to be the [patient's] spouse ... that the patient has tested positive on a test to detect infection by the probable causative agent of acquired immune deficiency syndrome."156 Statutes have also been passed spelling out the procedures for health care professionals to follow when reporting diseases to a government health authority. ${ }^{157}$ Both of these types of statutes protect a physician froin third party liability, thus preventing the type of liability that, in the recovered memory cases, threatens therapists and the psychological profession's ability to determine the validity of recovered nemory therapy.

Courts adjudicating HIV misdiagnosis cases should follow the lead set by this legislation. Given that the ELISA test, like the

153. Id. at 899 .

154. See Gordon v. Milwaukee County, 370 N.W.2d 803, 807 (Wis. Ct. App. 1985).

155. CAL. HeALTH \& SAFETY CODE \& 199.25(c) (West 1990).

156. Id. \& 199.25(a).

157. See Rodwin, supra note 83 , at 252 (commenting that the law regarding the physician's duty with respect to reporting AIDS and protecting public health is unresolved, "but the AMA and the American Psychiatric Association state that physicians are ethically obligated to divulge a patient's confidences and warn sexual partners known to be at risk of contagion"); see also AMERICAN MEDICAL ASSOCIATION, PRINCIPLES OF MEDICAL ETHICs \& 9, at $369 \mathrm{n} .175$ (1957) (stating that confidentiality must give way where "necessary to protect the welfare of the imdividual or [of] the community"); Canadian Doctors Authorize Sexual Partner Notification, 2 AIDS Policy \& Law (BNA) No. 17, at 4 (Sept. 9, 1987) (reporting that the Canadian Medical Association (CMA) voted to allow physicians to violate patient confidentiality and to tell the sexual partners of AIDS patients that they are at risk). 
Pap smear test, is not $100 \%$ certain, ${ }^{158}$ and given the importance of encouraging physicians to share HIV test results with their patients, a physician's disclosure of test results should be privileged by a good faith immunity standard. This would place the burden on the plaintiff to demonstrate either bad faith or gross negligence on the part of the physician, ultimately preventing the fear of litigation from affecting a physician's willingness to perform ELISA tests.

Good faith immunity was not available to private individuals under common law, ${ }^{159}$ but it has been used recently by both legislatures and courts. ${ }^{160}$ It has been called a "workable balance of [individual] and societal interests without compromising to any real degree the safety and welfare of [the patient]."161 Thus, it would protect the physician while allowing recovery by a patient who has been treated with reckless disregard or purposeful negligence.

\section{CONCLUSION}

It is dangerous to equate uncertain medical technology with physician negligence. The legal system must prevent limitless physician liability and allow space for medical testing to develop and improve. Thus, like the recovered memory cases and the Pap smear cases, the HIV misdiagnosis cases should be approached with a more careful concern for the issues underlying physician liability. In order to better protect physicians and the technology on which they rely, a good faith immunity standard should be applied in cases where HIV has been misdiagnosed.

158. See supra notes 9-10 and accompanying text.

159. See Cristine Kuhn, Note, Between Scylla and Charybdis: Can the Supreme Court Rescue the Inimical Qualified Immunity Doctrine?, 43 DRAKE L. REV. 681, $697-98$ (1995) (noting the distinction between qualified immunity, based on an objective standard, and the good faith defense, requiring the court to consider subjective factors).

160. For the most recent example of the use of good faith immunity standard, see the "right to die" cases. In these cases, physicians who follow the dictates of a living will are protected as long as they act (or refrain from acting) in good faith. See, e.g., John F. Kennedy Mem'l Hosp. v. Bludworth, 452 So. 2d 921, 926 (Fla. 1984) (holding that physicians need only act in good faith to avoid hability with respect to a right to die case); see generally Mark Strasser, Incompetents and the Right to Die: In Search of Consistent Meaningful Standards, 83 KY. L.J. 733, 799 (1995) (stating that "[p]hysicians who treat or fail to treat should be immune from liability as long as their decisions to act or refrain from acting are made in good faith").

161. Eric P. Gifford, 42 U.S.C. \& 1983 and Social Worker Immunity: A Cause of Action Denied, 26 TEX. TECH L. REV. 1013, 1038 (1995). 
